\title{
The Role of Ground in the Energy Management inside a Broiler House
}

\author{
Grzegorz Nawalany (Corresponding author) \\ Department of Rural Building, University of Agriculture Kraków, \\ 30-059, Al. Mickiewicza 24-28, Poland \\ Tel: 48-126-624-009Ｅ-mail: g.nawalany@ur.krakow.pl
}

Received: November 24, 2011

Accepted: December 12, 2011

Online Published: February 2, 2012

doi:10.5539/jas.v4n4p171

URL: http://dx.doi.org/10.5539/jas.v4n4p171

\begin{abstract}
The article confirms the hypothesis that appropriate utilization of heat capacity of ground beneath a broiler house and in its vicinity may support the management of indoor thermal conditions.

The research was conducted in a broiler house situated in the south of Poland. The broiler house, with a production hall of $1,000 \mathrm{~m}^{2}$, was bred with Ross chickens.

A detailed analysis was conducted for selected 2 production cycles: a summer and a winter one, including technological breaks. Air and ground temperature distribution was presented in a graphic form. Also, temperature fields in the ground and heat flux directions were established.

In the summer periods, the ground beneath the building acts as the main, and sometimes the sole, receiver of heat surplus from the litter.

The established directions of heat flux in the ground in winter suggest that it is possible to limit heat losses from the ground beneath the broiler house to the outside zone. Heat losses in winter may be decreased by insulating foundations. This will not interfere with the outflow of heat surplus from the broiler living area.
\end{abstract}

Keywords: Broiler house, Ground, Temperature, Heat transfer directions, Thermal conditions

\section{Introduction}

It is generally assumed that most significant factors shaping temperature conditions in the broiler living zone include indoor air temperature $\left(\Theta_{\mathrm{i}}\right)$, population density and litter temperature $\left(\Theta_{\mathrm{L}}\right)$. Temperature relations in litter, which covers a non-insulated concrete floor situated directly on soil, are influenced by heat from chicken bodies, heat emitted by fermenting chicken droppings and heat from the ground beneath. Results of research by Bieda (1978) and Nawalany et al. (2002, 2003, 2004, 2005) conducted in various livestock buildings confirmed that heat exchange with the ground plays a significant role in the management of indoor thermal conditions. Consequently, it could be stated that ground beneath a broiler house exerts major influence on temperature conditions inside. Thus, appropriate utilization of ground heat capacity may support the management of thermal conditions inside a broiler house.

In unbuilt-up areas, temperature fluctuations in the ground $\left(\Theta_{\mathrm{G}}\right)$ mainly depend on external air temperature $\left(\Theta_{\mathrm{e}}\right)$, type of vegetation, exposure, incline, soil type, soil humidity, groundwater level, etc. Temperature fluctuations are most significant in the uppermost ground layer, whilst at the depth of approximately $10 \mathrm{~m}$, the temperature is stable and close to annual average temperature $\left(\Theta_{\mathrm{e}}\right)$ for the given area (Popiel et al., 2001). Temperature fluctuations and temperature distribution become more complex in the ground around heated buildings, especially heated intermittently. This is particularly exemplified by broiler houses, where during a 6-week breeding cycle, $\Theta_{\mathrm{i}}$ changes from $33-34^{\circ} \mathrm{C}$ to $18-20^{\circ} \mathrm{C}$; whilst during technological breaks, heating is turned off completely. At that time, the ground becomes an especially important factor in energy management due to its high thermal capacity.

Research conducted in real operating conditions of a mass scale broiler house revealed that litter plays a dominating role in indoor temperature management. It has been concluded that, during the first 5 days of the winter production cycle, litter temperature $\left(\Theta_{\mathrm{L}}\right)$ was lower by even $14 \mathrm{~K}$ from the optimal temperature required 
at this stage of the breeding process $\left(\Theta_{\mathrm{opt}}\right)$; whilst in the last 20-25 days of the summer cycle, $\Theta_{\mathrm{L}}$ was higher from $\Theta_{\text {opt }}$ by as much as $15 \mathrm{~K}$ (Bieda and Koźbiał, 1999; Bieda et al., 2003, Nawalany et al. 2004). The significant difference between $\Theta_{\text {opt }}$ and $\Theta_{\mathrm{L}}$ confirms that operative temperature $\left(\Theta_{0}\right)$ in the broiler living zone was unfavourable during the major part of the production cycle (Nawalany, 2012). Outcomes of numerous studies clearly point out the need to ensure proper temperature and humidity of litter - the only partition that comes in direct contact with birds (Bessei, 2006, Nawalany et al., 2010). Dawkins and co-authors (2004) as well as Bieda and Nawalany (2006) agreed that broiler population exerts less influence on broiler house temperature than litter temperature and humidity.

Specialist literature devotes much attention to the optimization of litter quality, its microbiological and physicochemical properties (Jodas and Hafez, 2000; Veldman, 2004) or improvement of chicken welfare (Dawkins et al., 2004; Bessei, 2006; Meluzzi and Sirri, 2009); whilst the influence of ground beneath the broiler house on litter temperature has not been researched extensively.

A detailed analysis of temperature distribution in the ground around the broiler house throughout a sufficiently long period and across a sufficiently large space, which has been the main aim of the research, will help to evaluate the influence of ground on broiler house temperature and establish real boundary conditions for the calculations of heat exchange between the broiler house and the ground. The results will also aid in establishing appropriate thermal and insulation parameters of the floor and foundations; consequently, bird welfare and energy management will be much improved.

\section{Materials and Methods}

\subsection{Research Object}

The research was conducted in a broiler farm situated in the south of Poland $\left(49^{\circ} 848^{\prime} \mathrm{N}, 20^{\circ} 358^{\prime} \mathrm{E}\right)$. The broiler house, with a production hall of $1,000 \mathrm{~m}^{2}$, was located on an east-west axis. Prior each production cycle, the non-insulated concrete floor was covered with a 10-centimetre layer of long straw (barley and wheat). The broiler house was equipped with a forced-air heating system, vertical mechanical ventilation and a fogging system - all were controlled automatically. No bacterial or viral diseases which would significantly affect the production process and its results were observed during the researched production cycles.

Production results in the winter and summer cycles have been presented in Table 1.

\subsection{Temperature Measurement Points and Measurement Devices}

The research was conducted in a selected area of $18 \mathrm{~m}^{2}$ situated in the central part of the production hall, between the longitudinal axis of the building and its external wall (Fig. 1a). Temperature measurement points in the ground were located along 3 vertical measurement lines (Fig. $1 \mathrm{~b}$ and 1c).

Measurement devices included the following: a multichannel HP logger and 14 PT-100 sensors exact to $0.1^{\circ} \mathrm{C}$ and a standard terror of $\pm 0.1^{\circ} \mathrm{C}$. The sensors measured ground as well as inner and outer air temperatures.

The measurements were registered every 1 hour. Such a frequency was justified by previous research devoted to heat exchange between buildings and the ground. The measurements, which embraced 7 production cycles and 6 technological breaks, were conducted from 4 June 2004 to 22 August 2005.

\section{Research Results and Analysis}

The results of temperature measurements conducted for 14 months have been presented in a graphic form (Fig. 2) as daily-average values of indoor $\left(\Theta_{\mathrm{i}}\right)$, and exterior $\left(\Theta_{\mathrm{e}}\right)$ air temperature as well as temperature of the ground $\left(\Theta_{\mathrm{G}}\right)$ and litter $\left(\Theta_{\mathrm{L}}\right)$. A sinusoidal shape of $\Theta_{\mathrm{e}}$ and a specific shape of $\Theta_{\mathrm{i}}$ significantly influence the course of $\Theta_{\mathrm{G}}$ beneath and around the broiler house. Temperature of ground beneath the broiler house (cross-section A and B) are primarily shaped by $\Theta_{\mathrm{i}}, \Theta_{\mathrm{L}}$ and population density; whilst thermal conditions in the ground around the broiler house (cross-section $\mathrm{C}$ ) depend on outside climate as well as floor and partition construction and materials. In the researched period, annual average temperature $\Theta_{\mathrm{e}}$ equalled $11.2^{\circ} \mathrm{C}$, highest daily average $\Theta_{\mathrm{e}}$ occurred in the $2^{\text {nd }}$ production cycle and equalled $17.8^{\circ} \mathrm{C}\left(\Theta_{\text {emin }}=10.9^{\circ} \mathrm{C}, \Theta_{\text {emax }}=25.7^{\circ} \mathrm{C}\right)$. On the other hand, the lowest daily average $\Theta_{\mathrm{e}}=-0.2^{\circ} \mathrm{C},\left(\Theta_{\mathrm{emin}}=-14.2^{\circ} \mathrm{C}, \Theta_{\mathrm{emax}}=9.7^{\circ} \mathrm{C}\right)$ occurred in the winter cycle. Results of air and ground temperature measurements along particular measurement lines reveal a characteristic shift in time of extreme temperatures $\Theta_{\mathrm{G}}$ at particular measurement levels. This shift was most significant in the near-wall zone in the winter period: it lasted 14 days. Whereas the smallest shift in time appeared along the longitudinal axis in the summer period and it lasted 6 days.

As far as $\Theta_{\mathrm{G}}$ is concerned, it is important to note that throughout the entire year the largest temperature fluctuations occurred just beneath the floor. 
A detailed analysis was conducted for 2 production cycles: a summer cycle (9 August - 21 September 2004) and a winter cycle (24 December 2004 - 8 February 2005) together with technological breaks. Temperature distribution in the ground during these production cycles and technological breaks has been presented in Figures 3 and 4.

\subsection{Summer Production Cycle}

In the summer cycle, ground temperature beneath the broiler house decreased with depth and the difference between temperature at $-0.1 \mathrm{~m}$ and $-1.5 \mathrm{~m}$ was as much as $9 \mathrm{~K}$. During the technological break (when the heating was turned off), the ground under the broiler house cooled by $10 \mathrm{~K}$ in average. On 7 January 2004, when the production hall was being heated before housing, ground temperature increased as well. $\Theta_{\mathrm{G}}$ rose fastest in the top layer of ground, whilst the increase of $\Theta_{\mathrm{G}}$ in deeper layers occurred with a certain delay. This delay ranged from 1 day at the level $0.5 \mathrm{~m}$ to 7 days at $-1.5 \mathrm{~m}$.

\subsection{Winter Production Cycle}

In winter, $\Theta_{\mathrm{G}}$ varied not only depending on depth but also depending on the position against the longitudinal axis. For example, the difference of $\Theta_{\mathrm{G}}$ between cross-sections $\mathrm{A}$ and $\mathrm{B}$ at the same depth was approximately $3 \mathrm{~K}$ at the beginning of the production cycle and $5 \mathrm{~K}$ at the end of it.

\subsection{Temperature Fields in the Ground and Heat Flux Directions}

Having defined temperature distribution in the ground beneath and around the studied greenhouse, it was possible to establish temperature fields and appropriate heat transfer directions (Fig. 5 and 6). The figures present the dynamics of heat flux changes and heat exchange between the broiler house and the ground.

The distribution of temperature fields and heat flux directions at the beginning and towards the end of the winter technological break (Fig. 5ab) indicate a simultaneous outflow of heat accumulated beneath the broiler house to the indoor air and deeper layers of ground (see Fig. 5a) and consequently to the outside air. As a result, after several days without heating, the uppermost layer of ground cooled by approximately $15 \mathrm{~K}$, particularly in the central zone of the broiler house. In the near-wall zone of the building, the temperature fell insignificantly, by only a few degrees, yet the outflow of heat from beneath the broiler house to the outside air brought about a local increase of ground temperature.

During summer technological breaks, one could observe a steady movement of heat flux from the ground beneath the broiler house. It also needs to be noted that at the beginning of the technological break (see Fig. 5c) the heat was also continuously transferred to deeper ground layers. After several days without heating, the layer of ground situated directly below the concrete floor cooled by approximately $10 \mathrm{~K}$. The distribution of $\Theta_{\mathrm{G}}$ after the summer technological break is much more favourable for the incoming production cycle than after a similar break in the winter season, because heating the broiler house and the ground beneath requires significantly lower energy expenditure.

In the first days of the winter production cycle (up to day 4), the heat flew from the indoor air to deeper layers of ground beneath the central part of the broiler house. In the near-wall zone, the heat was transferred to the outdoor zone and further to the outside air. In the first day of the winter production cycle, the heat accumulated in deeper ground layers moved upwards to the layers that had cooled most significantly during the technological break. At the same time, the heat also transferred from the broiler house to the ground. From day 3 towards the end of the breeding cycle, the heat flew continuously from the broiler house to the ground; and after about 2 weeks, litter played a dominating role here, which means that not only did it transmit heat to the ground but also to the indoor air. Such a situation maintained till the end of the breeding cycle. Over the entire production cycle, heat from the near-wall zone was transferred to the outside zone and further to the outside air.

The summer production cycle began with the outflow of heat from the broiler house to the uppermost layer of ground; yet in the central part of the building the heat was also transmitted from deeper ground layers upwards. From day 3 onwards, heat flux moved towards the ground across the entire floor area. After approximately 10 days of the production cycle, so a few days earlier than in the winter season, the litter started to be a dominating factor and transmitted accumulated heat to the indoor air and ground beneath the broiler house and around it. This state was sustained till the end of the production cycle.

The analysis of temperature field distributions in the ground reveals that thermal conditions inside the broiler house in winter affected the ground adjoining the building. At the same time, it was observed that the outdoor climate influenced heat outflow directions from the floor to the ground only in the near-wall zone. In the summer period, this influence disappeared so there were no differences in heat movement between the ground in the central and near-wall zone, like in the winter season. 
In the light of conducted research, it can be concluded that the role of ground in the development of thermal condition inside a broiler house may be favourable or unfavourable and it may change over a particular production cycle or in a given year.

\section{Discussion}

Studies conducted by Dawkins et al. (2004) with various bird species in mass scale production farms confirm that controlling litter quality, its temperature and humidity were more important than population reductions. Also research presented by Bessei (2006) confirms that high stocking density limits heat movement from litter to the air, thus increasing the temperature of litter. Also results of multiannual research conducted by Bieda and Nawalany et al. (2006) confirm the statement that higher stock density increases $\Theta_{\mathrm{L}}$. The effectiveness of thermal insulation applied in the floor, which is a standard in heated buildings, was not confirmed by Nawalany et al. (2006). A yearly experiment with a thermally insulated floor $(5 \mathrm{~cm} \mathrm{XPS})$ in a broiler house for 20 thousand broiler chickens revealed that litter temperature increases, which turned very favourable to the first week of breeding. However, during the last 3 days, the influence was definitely negative because it led to significant growth of $\Theta_{\mathrm{L}}$ relative to the required $\Theta_{\text {opt }}$.

Previous multiannual observations of temperature distribution in production cycles conducted by the author in various seasons of the year confirmed that ground significantly influenced thermal conditions in the broiler living zone. In the first days of the production cycle, the ground beneath the broiler house was cooled after the technological break to the temperature of about $10^{\circ} \mathrm{C}$ in the winter period and $20^{\circ} \mathrm{C}$ in the summer period. This caused water vapour condensation on the concrete floor. The vapour was absorbed by the litter, which significantly decreased its heat and insulation properties, thus deteriorating thermal conditions in the living zone. However in the second part of the production cycle, the ground became the main and sole receiver of heat from the litter, which significantly limited the growth of litter temperature and temperature of the living zone. Therefore thanks to considerable heat capacity, the ground helped to protect the birds against discomfort and thermal stress.

Temperature fields around the broiler house were influenced mainly by thermal conditions inside the production hall, outside climate, material and construction solutions applied for foundation walls and floor, which were not equipped with thermal insulation. The influence of outdoor climate clearly increased in the winter season when ground temperature outside the building at the depth of $0.5 \mathrm{~m}$ fell to approximately $-2^{\circ} \mathrm{C}$ and at the depth of 1.5 $\mathrm{m}$ to approximately $6^{\circ} \mathrm{C}$. Isotherm distribution and respective directions of heat flux indicate that in the near-wall zone of the broiler house heat radiated to the ground outside the building and to the outside air.

In the summer period, when temperature difference between the ground beneath the building and the ground in the outside zone was significantly lower (prior the production cycle it equalled $2 \mathrm{~K}$ and in the last week of breeding $-8 \mathrm{~K}$ ), heat exchange between those zones was insignificant. Heat flux directions presented in Figure 5 and 6 reveal that during the technological break, the heat accumulated in the ground beneath the floor returned to the broiler house. The situation continued in the first days of the production cycle; yet after a few days, the heat flux moved in the opposite direction. Summing up, it may be concluded that in the winter production cycle and in the outside ground zone, heat flux moved towards the outside air; in the summer cycle, the ground both beneath the broiler house and around it acted as heat receiver.

The established directions of heat flux in the ground in winter suggest that it is possible to limit heat loss from beneath the broiler house to the outdoor zone. Heat losses in the winter period may be decreased by installing vertical thermal insulation of foundations or ground beams. Such a solution will not interfere with the favourable flow of excessive heat from the litter to the ground in the summer season.

Shortening the technological break may also be of key importance for thermal conditions in first stages of the production cycle. As a result, more heat accumulated in the ground during the previous production cycle would be used to shape appropriate thermal conditions in the broiler living zone.

A detailed calculation analysis is therefore necessary in order to define optimal heat and insulation parameters of the floor and thermal vertical insulation between the near-wall zone and the outside zone. Based on these results, it will be possible to develop recommendations for broiler production concerning the management of optimal conditions inside a broiler living zone as well as rationalization of energy management inside a broiler house.

\section{References}

Bessei, W. (2006). Welfare of broilers: a review. World's Poultry Science Journal, 62, 455-466, http://dx.doi.org/10.1079/WPS2005108 
Bieda, W., Koźbiał, M. (1999). Effect of litter, floor and ground on thermal conditions of broiler house in the winter period (in polish). Roczniki Nauk Zootechnicznych, 26, 265-274.

Bieda, W., Nawalany, G. (2006). Effect of broiler-house stocking density on temperature of bedding and thermal conditions in the living area of birds. Annals of Animals Science, 6, 321-330.

Bieda, W., Nawalany, G., Radoń, J. (2003). Temperature of bedding during floor keeping of broilers. In: Elimination of Agricultural Risks to Health and Environment. Scientific Network "Agrorisks". IBMER, Warszawa, 199-203.

Dawkins, M.S. Donelly, S. Jones, T.A. (2004). Chicken welfare is influenced more by housing conditions than by stocking density. Nature, 427, 342-344. http://dx.doi.org/10.1038/nature02226.

Jodas, S., Hafez, H.M. (2000). Litter management and related diseases In turkeys. World Poultry, 12(6), 19-22.

Meluzzi, A., Sirri, F. (2009). Welfare of broiler chickens. Italian Journal of Animal Science, 8(1), 161-173.

Nawalany, G., Bieda, W. (2002). Heat exchange between the Ground and hollowed fruit store and fruit cold store (in polish). Acta Sci. Pol. Architektura, 1-2, 17-27.

Nawalany, G., Bieda, W., Radoń, J. (2003). Temperature distribution in ground in surroundings of hollowed fruit cold store (in polish). Acta Sci. Pol. - Formatio Circumiectus, 2,117-128.

Nawalany, G., Bieda, W., Radoń, J. (2004). Thermal and moisture parameters of broiler house litter in light of research. Annals of Animal Science, 1, 193-196.

Nawalany, G., Bieda, W., Radoń, J. (2005). Temperature distribution in the ground in surroundings of a building heated periodically on the example of a broiler house (in polish). Zesz. Nauk. AR w Krakowie, ser. Inż. Środowiska, 26, 475-482.

Nawalany, G., Bieda, W., Radoń, J. (2006). Effect of floor thermal insulation in broiler houses (in polish). Acta Sci. Pol. Architektura, 5 (1). 111-117.

Nawalany, G., Bieda, W., Radoń, J. (2010). Effect of floor heating and cooling of bedding on thermal conditions in the living area of broiler chickens. Arch. Geflügelk., 74(2), 98-101.

Nawalany, G. (2012). A proposal to apply operative temperature for the evaluation of thermal conditions in the broiler living zone. Arch. Geflügelk., 76(1).

Popiel, CO., Wojtkowiak, J., Biernacka, B. (2001). Measurements of temperature distribution in ground. Experimental Thermal and Fluid Science, 25:301-309.

Veldman, B. (2004). Carom pod meal to enhance liter quality. World Poultry, 20(9), 15.

Table 1. Production in the winter (24 December 2004 - 8 February 2005) and summer (9 August - 21 September 2004) production cycle

\begin{tabular}{|c|c|c|c|c|c|}
\hline \multirow{2}{*}{\multicolumn{2}{|c|}{$\begin{array}{c}\text { Cycle/ } \\
\text { Day of cycle }\end{array}$}} & \multirow{2}{*}{$\begin{array}{l}\text { Number } \\
\text { of chicken }\end{array}$} & \multirow{2}{*}{$\frac{\text { Weight }}{(\mathrm{kg})}$} & \multicolumn{2}{|c|}{ Stock density } \\
\hline & & & & $\left(\right.$ birds per $\left.\cdot \mathrm{m}^{-2}\right)$ & $\left(\mathrm{kg} \cdot \mathrm{m}^{-2}\right)$ \\
\hline \multirow{7}{*}{$\frac{\bar{\Phi}}{\Xi}$} & 1 & 18400 & - & - & - \\
\hline & 7 & 18293 & 3110 & 18.30 & 3.11 \\
\hline & 14 & 18197 & 6915 & 18.19 & 6.91 \\
\hline & 21 & 18135 & 14145 & 18.14 & 14.15 \\
\hline & 28 & 18094 & 24427 & 18.09 & 24.43 \\
\hline & 35 & 18061 & 32149 & 18.06 & 32.15 \\
\hline & 42 & 18020 & 37842 & 18.02 & 37.84 \\
\hline \multirow{7}{*}{$\begin{array}{l}\vec{\Xi} \\
\text { 音 } \\
\text { 品 }\end{array}$} & 1 & 17800 & - & - & - \\
\hline & 7 & 17692 & 3008 & 17.69 & 3.01 \\
\hline & 14 & 17637 & 8642 & 17.64 & 8.64 \\
\hline & 21 & 17575 & 14939 & 17.58 & 14.94 \\
\hline & 28 & 17519 & 27505 & 17.52 & 27.50 \\
\hline & 35 & 17459 & 31601 & 17.46 & 31.60 \\
\hline & 42 & 17412 & 38306 & 17.41 & 38.31 \\
\hline
\end{tabular}




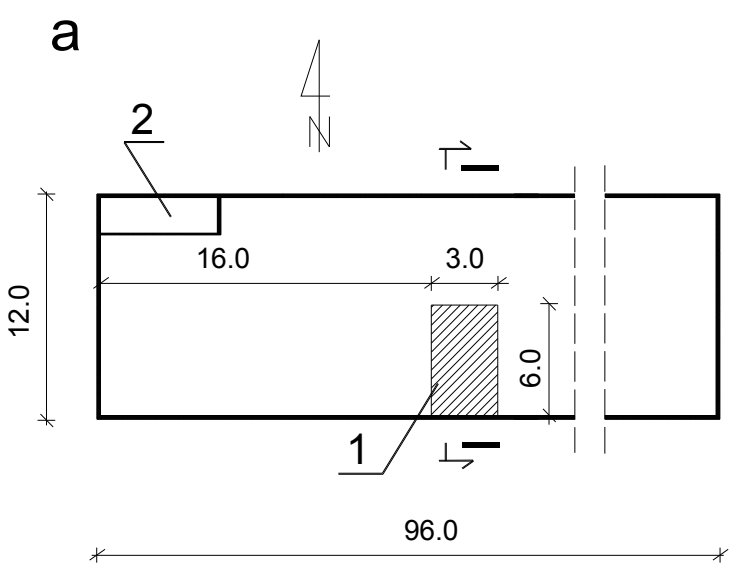

b

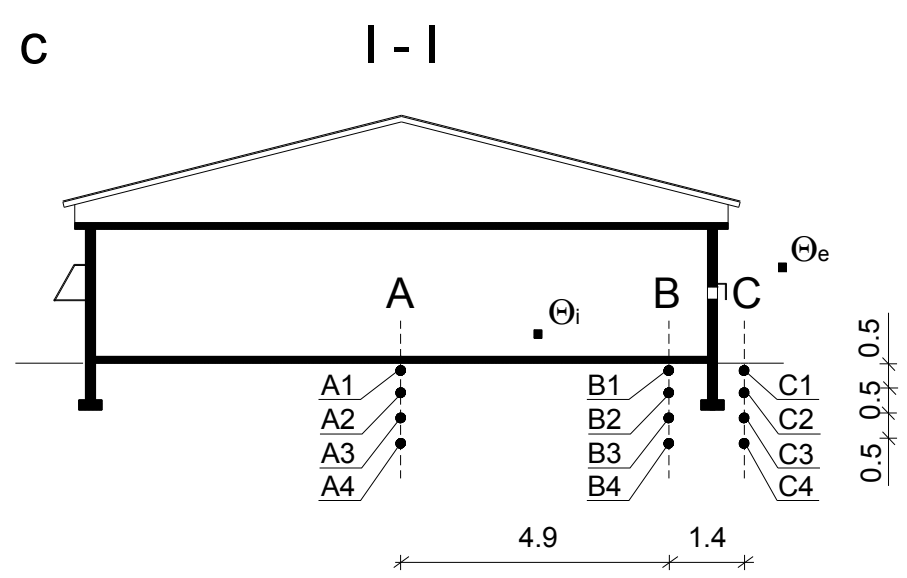

Figure 1. Orientation plan of the researched broiler house

a-projection

$\mathrm{b}$ - distribution of measurement points in the litter

$\mathrm{c}$ - cross-section

1 - temperature measurement field in litter

2 - control room

$\circ-$ temperature measurement points in litter

- - temperature measurement points in the ground

- - temperature measurement points in the air 
a

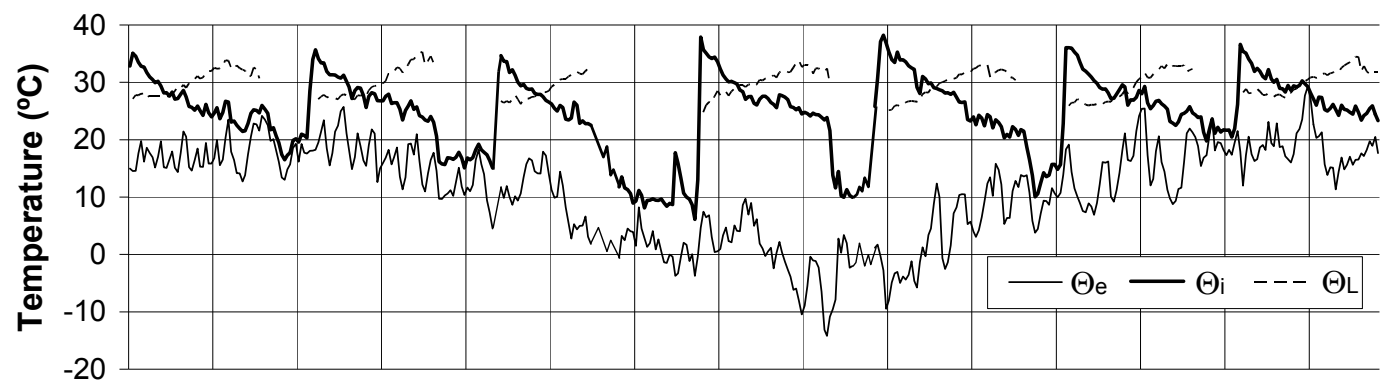

b

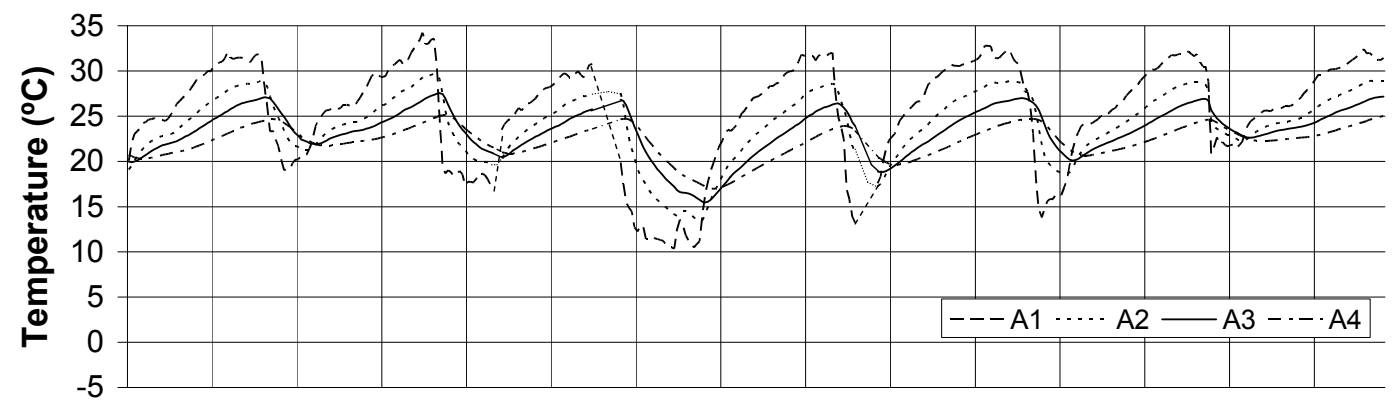

C

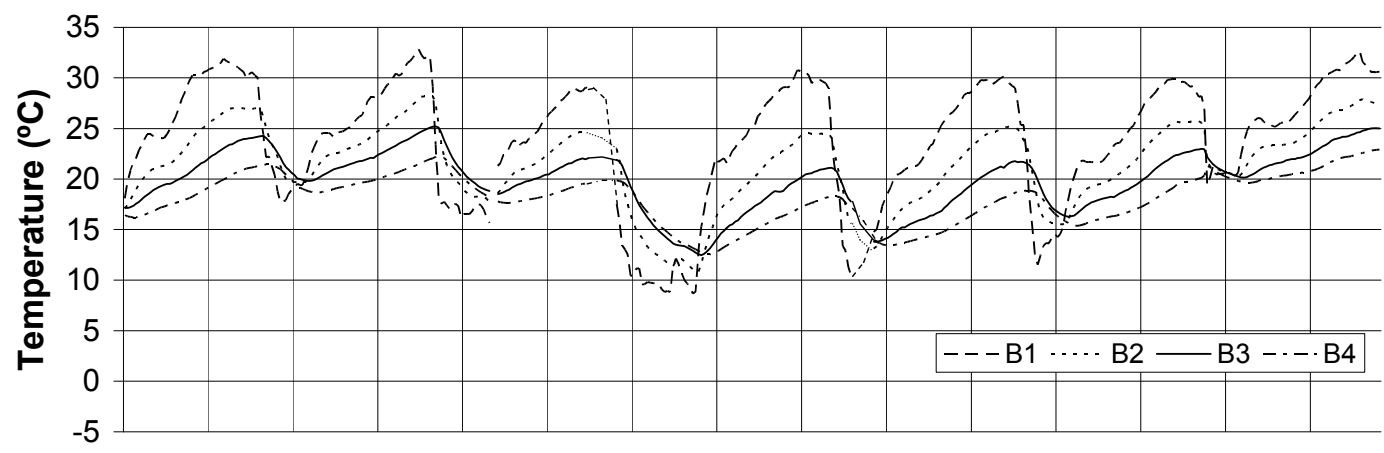

d

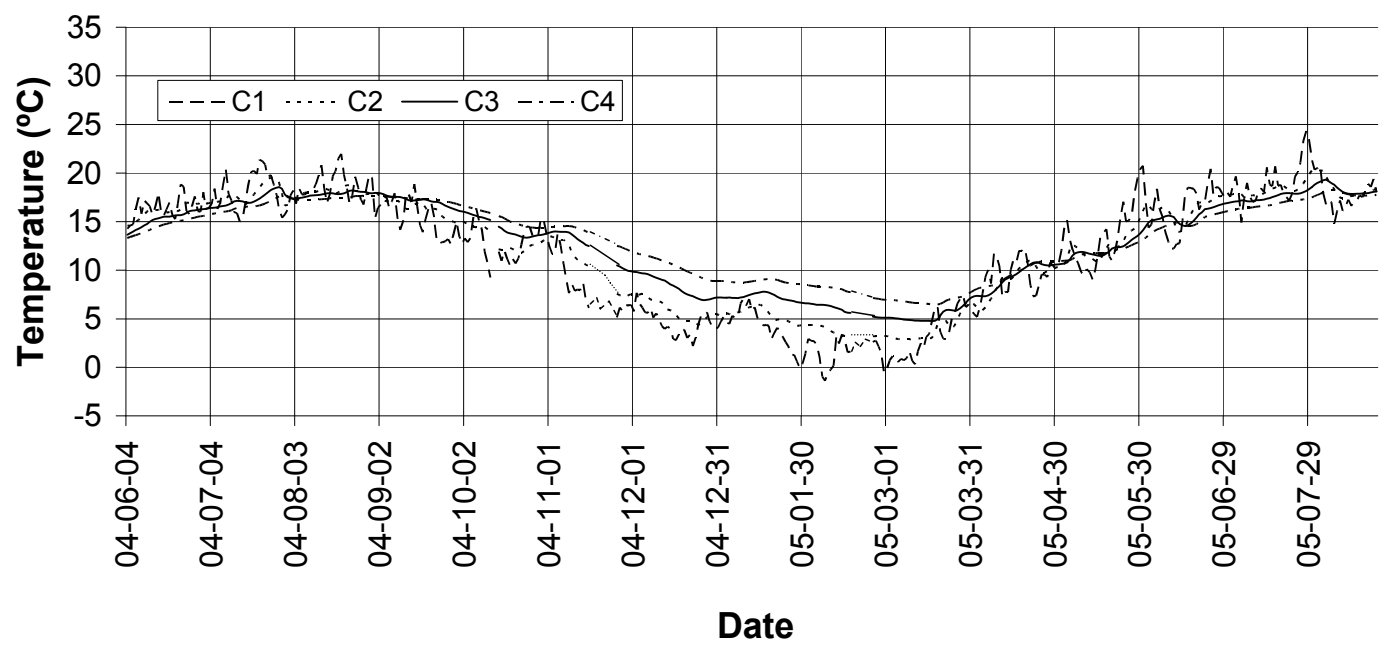

Figure 2. The distribution of daily average temperatures $\left(\Theta_{\mathrm{i}}\right.$ and $\left.\Theta_{\mathrm{e}}\right)$, in the litter $\Theta_{\mathrm{L}}$ and the ground (A1-A4;

B1-B4; C1-C4) from 4.06.2004 to 22.08.2005; $\mathrm{a}$ - air and litter temperature distribution, $\mathrm{b}$ - temperature distribution in the ground in the measurement line $\mathrm{A}, \mathrm{c}-$ temperature distribution in the measurement line $\mathrm{B}, \mathrm{d}-$ temperature distribution in the ground in measurement line $\mathrm{C}$ 
a

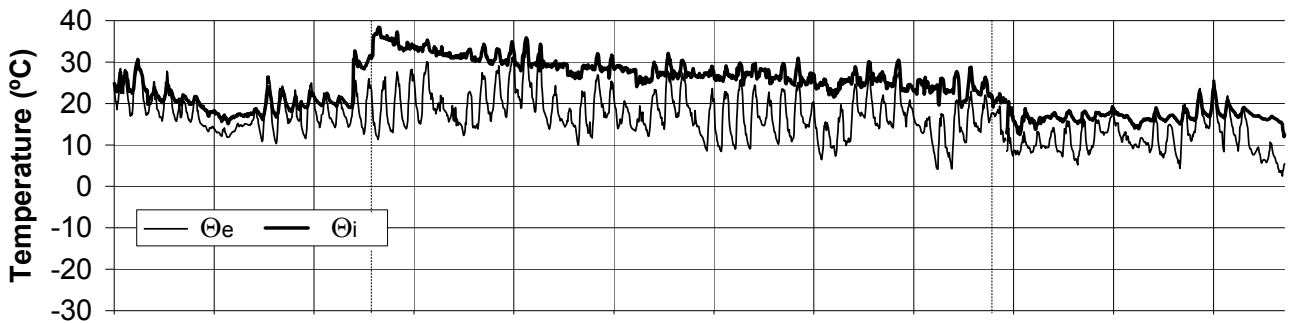

b

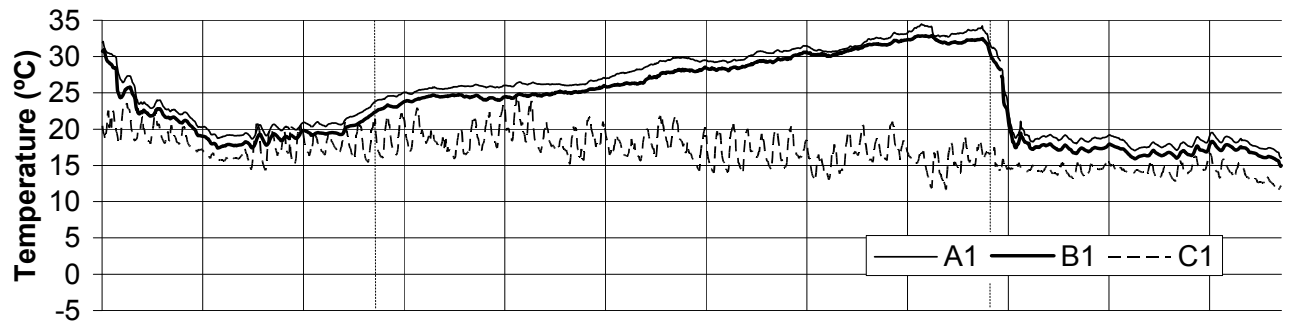

C

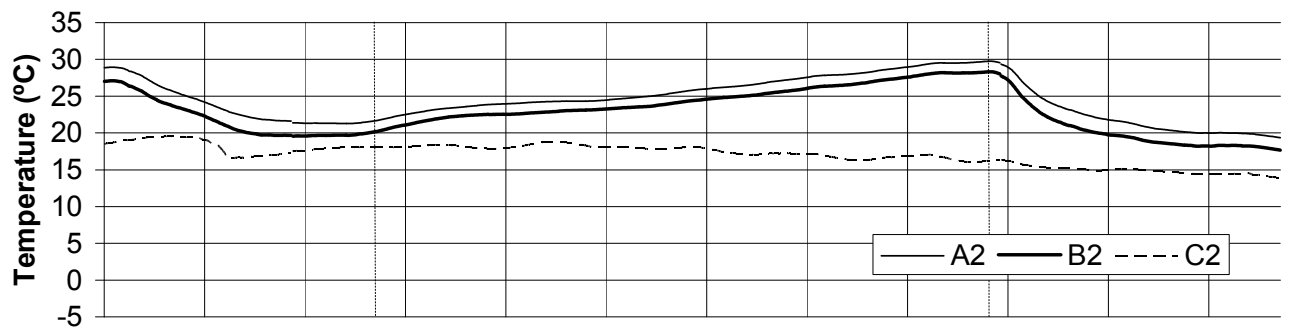

d

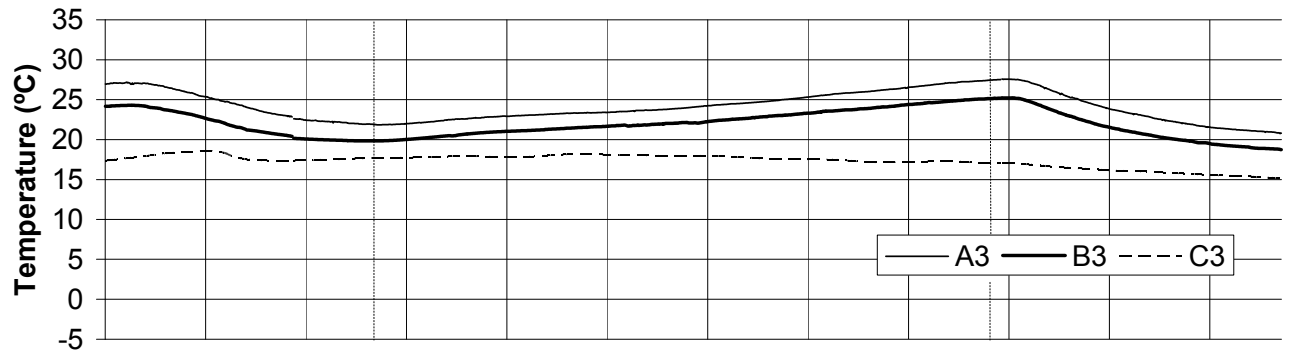

e

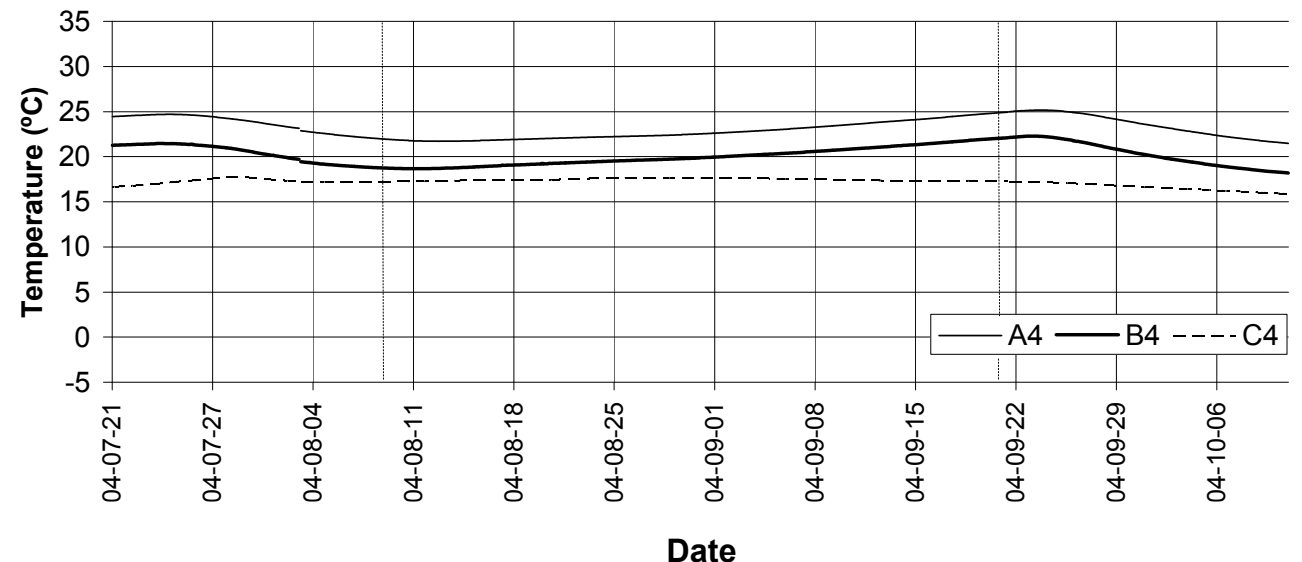

Figure 3. Hourly temperature distribution in the air and ground in the summer period ( 9 August -21 September 2004); $\mathrm{a}$ - air temperature distribution $\left(\Theta_{\mathrm{i}}\right.$ and $\left.\Theta_{\mathrm{e}}\right), \mathrm{b}$ - ground temperature distribution at the depth of -0.05

$(\mathrm{A} 1 ; \mathrm{B} 1 ; \mathrm{C} 1), \mathrm{c}-$ ground temperature distribution at the depth of $-0.5(\mathrm{~A} 2 ; \mathrm{B} 2 ; \mathrm{C} 2), \mathrm{c}-$ ground temperature distribution at the depth of $-1.00(\mathrm{~A} 3 ; \mathrm{B} 3 ; \mathrm{C} 3), \mathrm{d}$ - ground temperature distribution at the depth of -1.50 

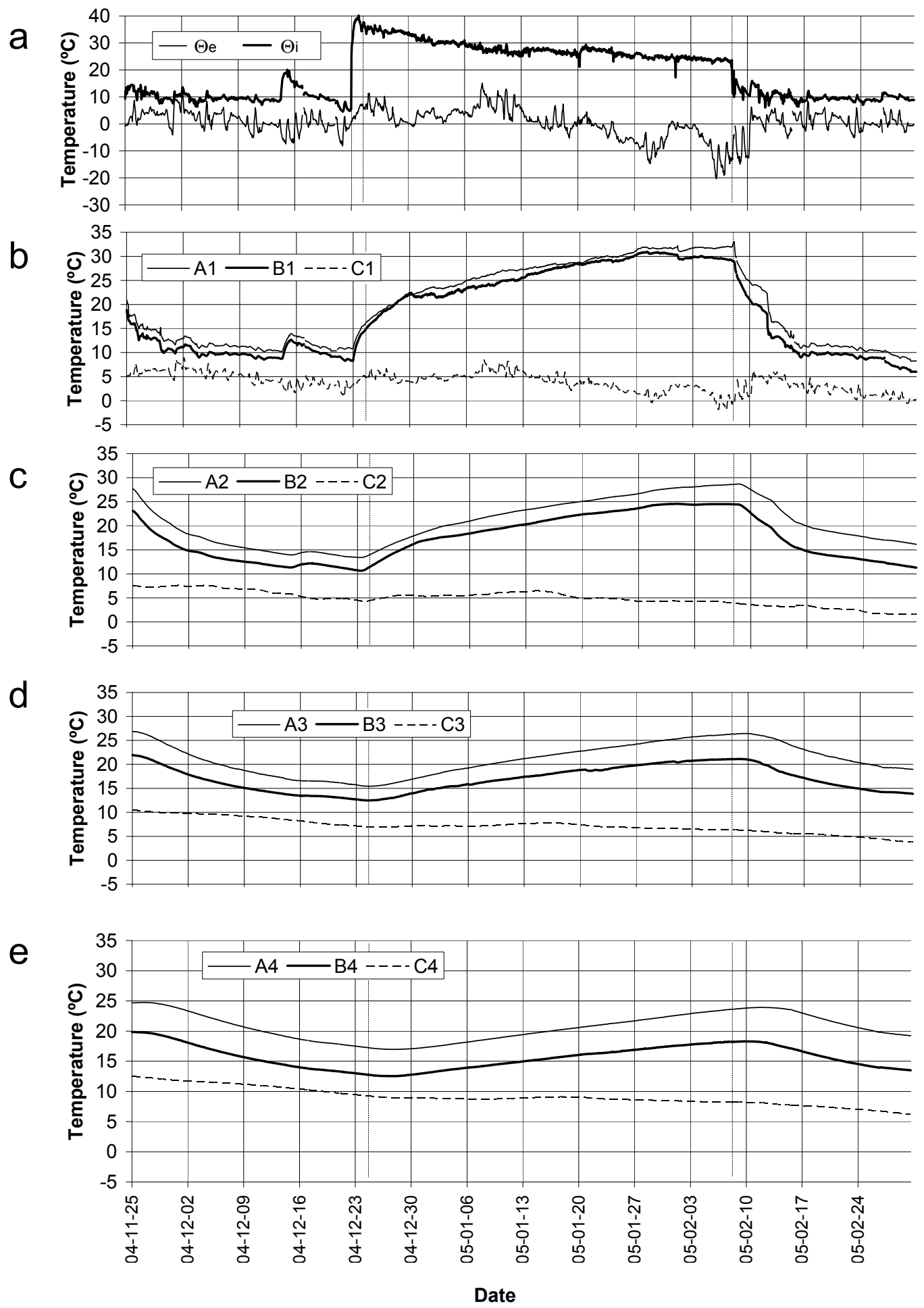

Figure 4. Hourly temperature distribution in the air and ground in the winter period (24 December $2004-8$ February 2005); $\mathrm{a}$ - air temperature distribution $\left(\Theta_{\mathrm{i}}\right.$ and $\left.\Theta_{\mathrm{e}}\right), \mathrm{b}$ - ground temperature distribution at the depth of $-0.05(\mathrm{~A} 1 ; \mathrm{B} 1 ; \mathrm{C} 1), \mathrm{c}-$ ground temperature distribution at the depth of $-0.5(\mathrm{~A} 2 ; \mathrm{B} 2 ; \mathrm{C} 2), \mathrm{c}-$ ground temperature distribution at the depth of $-1.00(\mathrm{~A} 3 ; \mathrm{B} 3 ; \mathrm{C} 3), \mathrm{d}$ - ground temperature distribution at the depth of -1.50

$$
(\mathrm{A} 4 ; \mathrm{B} 4 ; \mathrm{C} 4)
$$



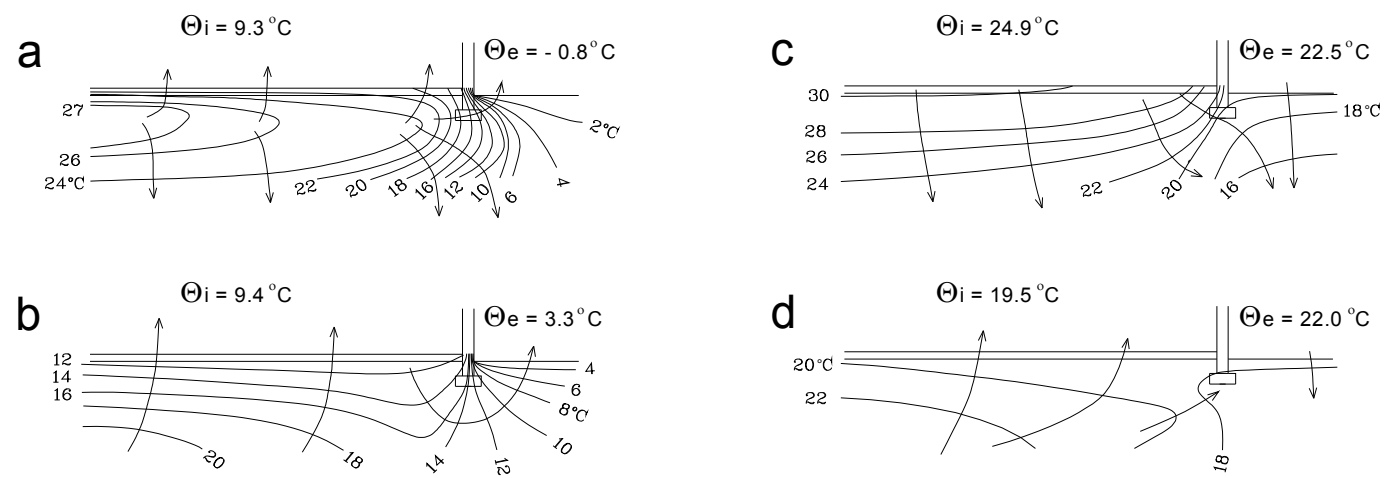

Figure 5. Temperature fields and heat flux directions in the ground beneath the broiler house during technological breaks: a - day 2 of the technological break in the winter period ( 25 November 2004), b - day 15 of the break in the winter season (8 December 2004), c - day 2 of the break in the summer season (21 July 2005),
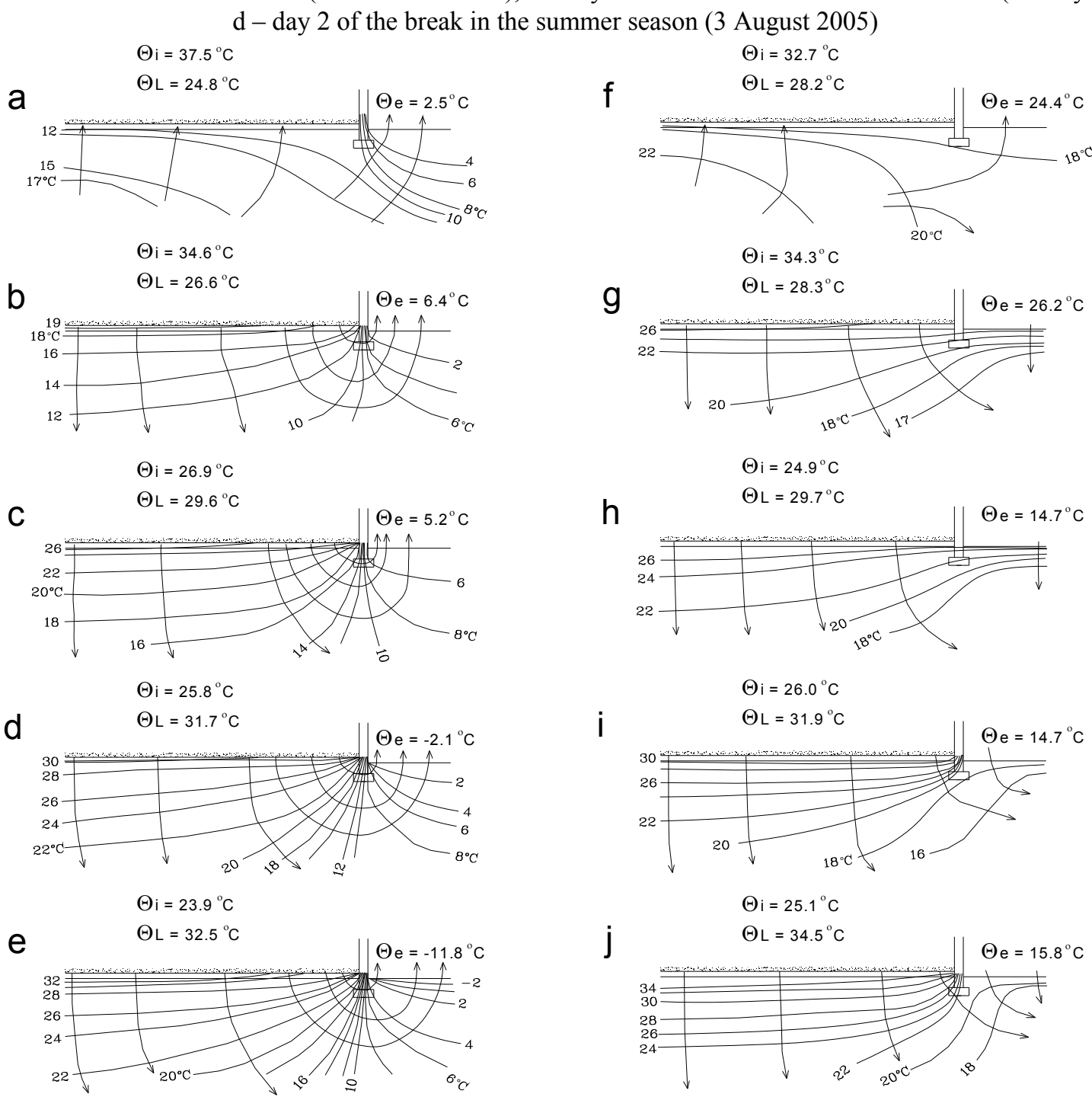

Figure 6. Temperature fields and heat flux directions in the ground beneath the broiler house during production cycles: a - day 1 of the winter production cycle (24 December 2004), b - day 3 of the winter production cycle

(27 December 2004), c - day 17 of the winter production cycle (10 January 2005), d - day 31 of the winter production cycle (24 January 2005), e - day 42 of the winter production cycle (4 February 2005), f - day 1 of the summer production cycle (9 August 2005), g - day 3 of the summer production cycle (12 August 2005), h - day 17 of the summer production cycle (26 August 2005), i - day 31 of the summer production cycle (9 September 2005), $\mathrm{j}$ - day 42 of the summer production cycle (20 September 2005) 